\title{
On the Magma Chambers beneath Klyuchevskoi Volcano, Kamchatka
}

\author{
S. A. Khubunaya ${ }^{a, *}$, L. I. Gontovaya ${ }^{a}$, A. V. Sobolev ${ }^{b, * *}$, and V. S. Khubunaya ${ }^{a}$ \\ ${ }^{a}$ Institute of Volcanology and Seismology, Far East Branch, Russian Academy of Sciences, \\ bul'var Piipa, 9, Petropavlovsk-Kamchatskii, 683006 Russia \\ ${ }^{b}$ Vernadsky Institute of Geochemistry and Analytical Chemistry, \\ Russian Academy of Sciences, ul. Kosygina, 19, Moscow, 119311 Russia \\ *e-mail: hubsa@kscnet.ru \\ **e-mail: sobolev@geokhi.ru \\ Received May 14, 2017
}

\begin{abstract}
Numerous summit and parasitic eruptions of moderate potassium magnesian and high-alumina basalts and basaltic andesites, their mineralogic and geochemical features, and the composition of in situ chilled melt inclusions in the olivine of cinder lapilli discharged by Klyuchevskoi Volcano all provide evidence of the presence of magma chambers beneath the volcano. This is also supported by a dualism in the variation of $\mathrm{CaO}$ and $\mathrm{Al}_{2} \mathrm{O}_{3}$ concentrations in olivine and clinopyroxene during crystallization. The mineralogic features in the high-alumina basalts that were discharged by all parasitic eruptions of Klyuchevskoi provide evidence of magnesian magma being emplaced from a deeper chamber into a shallow high-alumina chamber. The distribution of incoherent elements in the volcano's magnesian and aluminiferous rocks shows that they came from a single mantle source. The geochemical and mineralogic data are in good agreement with the results of geophysical surveys that concern the structure and properties of the lithosphere beneath Klyuchevskoi.
\end{abstract}

DOI: $10.1134 / \mathrm{S} 0742046318020045$

\section{INTRODUCTION}

The study of magma chambers beneath Klyuchevskoi is an urgent task in volcanology; it is intimately related to the genesis of volcanic rocks, the prediction of volcanic eruptions, and volcanic hazard. A.A. Menyailov (1947) was the first investigator to hypothesize the existence of a shallow stratified magma chamber beneath Klyuchevskoi during his study of the 1937-1938 Klyuchevskoi eruptions. This was also pointed out by B.I. Piip later, based on his study of Tertiary xenoliths in the lavas of parasitic eruptions on the Klyuchevskoi northeastern slope. He supposed that the magma chamber is no deeper than 5-6 km below sea level (Piip, 1956). Our inferences and the results of other researchers on possible magma chambers beneath Klyuchevskoi Volcano are based on a detailed study of the petrography, mineralogy, and geochemistry of its magnesian and high-alumina (aluminiferous) basalts and basaltic andesites discharged by most pre-historic, historic, and recent eruptions (Table 1).

Geophysical surveys of the lithosphere beneath Klyuchevskoi are no less important for understanding the plausible existence of magma chambers beneath Klyuchevskoi and their spatial locations. Extensive surveys have been carried out using the methods of seismology, geoelectricity, and gravimetry (Anosov et al., 1978; Zubin et al., 1990; Balesta et al., 1991; Gontovaya et al., 2004; Moroz, 1991; Moroz and Moroz, 2006; Fedotov et al., 2010, 2011, 2014; Koulakov et al., 2016; Ivanov et al., 2016). In recent years, seismic tomography began to be extensively used, probing the crust beneath Klyuchevskoi by seismic rays due to volcano-tectonic (VT) earthquakes. The use of this method is advantageous in that one can compare deep crustal models with other volcanoes worldwide and reveal some general features in their magmatic plumbing systems. It is important to compare the data derived by seismic tomography with those obtainable by the electromagnetic method, as the latter is the more sensitive to the presence of liquid melts. This permits one a more reliable correlation between zones of intensive seismic velocity anomalies and the magma sources that feed the volcano. Most researchers agree in recognizing an estimate of the depth of a primary magma source in the upper mantle and a magma chamber in the lower crust beneath Klyuchevskoi, while the existence of a shallow magma chamber beneath the volcanic cone is not unanimously accepted. The present paper argues for the existence of intermediate magma chambers beneath the Klyuchevskoi edifice by comparing the results of petrologic studies in the ejecta of pre-historical summit and parasitic eruptions of 1994, 1938, 1966, and 
Table 1. The representative compositions of basalts and basaltic andesites discharged by the Klyuchevskoi parasitic and summit eruptions

\begin{tabular}{|c|c|c|c|c|c|c|}
\hline $\begin{array}{l}\text { No./Oxides, } \\
\text { elements }\end{array}$ & 1 & 2 & 3 & 4 & 5 & 6 \\
\hline $\mathrm{SiO}_{2}$ & 51.98 & 53.42 & 53.68 & 54.11 & 54.15 & 53.80 \\
\hline $\mathrm{TiO}_{2}$ & 0.78 & 0.89 & 1.04 & 1.11 & 1.03 & 1.04 \\
\hline $\mathrm{Al}_{2} \mathrm{O}_{3}$ & 13.64 & 15.55 & 18.83 & 18.57 & 16.94 & 17.92 \\
\hline $\mathrm{FeO}$ & 8.47 & 8.04 & 8.18 & 8.23 & 8.32 & 8.45 \\
\hline $\mathrm{MnO}$ & 0.17 & 0.18 & 0.15 & 0.14 & 0.15 & 0.17 \\
\hline $\mathrm{MgO}$ & 11.00 & 7.71 & 4.86 & 4.72 & 5.98 & 4.86 \\
\hline $\mathrm{CaO}$ & 10.04 & 9.57 & 8.45 & 8.36 & 8.46 & 8.36 \\
\hline $\mathrm{Na}_{2} \mathrm{O}$ & 2.29 & 2.85 & 3.70 & 3.50 & 3.18 & 3.24 \\
\hline $\mathrm{K}_{2} \mathrm{O}$ & 0.59 & 0.89 & 1.09 & 1.08 & 1.06 & 1.12 \\
\hline $\mathrm{P}_{2} \mathrm{O}_{5}$ & 0.16 & 0.19 & 0.21 & 0.22 & 0.21 & 0.23 \\
\hline Total & 99.13 & 99.30 & 100.19 & 100.05 & 99.48 & 99.18 \\
\hline $\mathrm{Rb}$ & 9 & 13 & 16 & 16 & 16 & 17 \\
\hline $\mathrm{Ba}$ & 227 & 317 & 395 & 414 & 390 & 410 \\
\hline Th & 0.5 & 0.7 & 0.7 & 0.8 & 0.7 & 0.8 \\
\hline $\mathrm{U}$ & 0.3 & 0.3 & 0.5 & 0.5 & 0.4 & 0.4 \\
\hline $\mathrm{Nb}$ & 1.3 & 1.6 & 2.0 & 2.1 & 2.0 & 2.0 \\
\hline $\mathrm{Ta}$ & 0.09 & 0.12 & 0.13 & 0.14 & 0.13 & 0.14 \\
\hline K & 4898 & 7388 & 9049 & 8966 & 8800 & 9298 \\
\hline $\mathrm{La}$ & 4 & 6 & 7 & 7 & 7 & 7 \\
\hline $\mathrm{Ce}$ & 11 & 14 & 16 & 17 & 16 & 18 \\
\hline $\mathrm{Pb}$ & 1.9 & 2.2 & 5.5 & 2.9 & 1.7 & 2.6 \\
\hline $\operatorname{Pr}$ & 1.7 & 2.2 & 2.5 & 2.6 & 2.5 & 2.6 \\
\hline $\mathrm{Nd}$ & 9 & 11 & 13 & 13 & 13 & 14 \\
\hline $\mathrm{Sr}$ & 239 & 318 & 373 & 373 & 343 & 369 \\
\hline $\mathrm{Sm}$ & 2.7 & 3.0 & 3.41 & 3.7 & 3.5 & 3.7 \\
\hline $\mathrm{Zr}$ & 69 & 78 & 86 & 92 & 98 & 94 \\
\hline $\mathrm{Hf}$ & 1.8 & 1.9 & 2.2 & 2.4 & 2.3 & 2.2 \\
\hline $\mathrm{Eu}$ & 0.9 & 1.0 & 1.2 & 1.3 & 1.1 & 1.2 \\
\hline $\mathrm{Ti}$ & 4655 & 5179 & 6092 & 6640 & 6123 & 6280 \\
\hline $\mathrm{Gd}$ & 2.9 & 3.2 & 3.7 & 4.1 & 3.7 & 3.7 \\
\hline $\mathrm{Tb}$ & 0.5 & 0.5 & 0.6 & 0.6 & 0.61 & 0.6 \\
\hline Dy & 3.4 & 3.6 & 4.3 & 4.6 & 4.0 & 4.0 \\
\hline Но & 0.7 & 0.7 & 0.9 & 0.9 & 0.8 & 0.8 \\
\hline Y & 18 & 19 & 21 & 22 & 21 & 20 \\
\hline $\mathrm{Er}$ & 2 & 2 & 2 & 2 & 2 & 2 \\
\hline $\mathrm{Tm}$ & 0.3 & 0.3 & 0.3 & 0.3 & 0.3 & 0.3 \\
\hline $\mathrm{Yb}$ & 2.0 & 2.2 & 2.3 & 2.5 & 2.3 & 2.2 \\
\hline $\mathrm{Lu}$ & 0.30 & 0.32 & 0.34 & 0.37 & 0.35 & 0.35 \\
\hline $\mathrm{Ni}$ & 184 & 79 & 29 & 27 & 56 & 27 \\
\hline $\mathrm{Cu}$ & 71 & 70 & 94 & 98 & 70 & 87 \\
\hline $\mathrm{Zn}$ & 79 & 71 & 182 & 100 & 71 & 85 \\
\hline $\mathrm{Sc}$ & 42 & 36 & 27 & 29 & 31 & 30 \\
\hline $\mathrm{Zr}$ & 69 & 78 & 86 & 92 & 98 & 94 \\
\hline Co & 43 & 33 & 31 & 32 & 30 & 28 \\
\hline $\mathrm{Li}$ & 7 & 10 & 14 & 14 & 12 & 12 \\
\hline W & 0.07 & 0.08 & 0.16 & 0.14 & 0.10 & 0.12 \\
\hline
\end{tabular}

(1) magnesian basalt from a volcanic bomb ejected by the prehistorical nameless eruption; (2) magnesian basaltic andesite sampled from the Tiranus lava flow; (3) aluminiferous basaltic andesite sampled from the lava flow discharged by the 1994 summit eruption; (4) aluminiferous basaltic andesite sampled from the 1996 lava flow; (5) aluminiferous basaltic andesite sampled from the 1945 lava flow; (6) aluminiferous basaltic andesite sampled from the Nevidimka lava flow. The compositions of the oxides are in wt \%, those of accessory elements are in $\mathrm{g} / \mathrm{t}$. 
1945 with the seismic-density model of the upper crust beneath the volcano.

\section{MATERIALS AND METHODS}

The Technique of Sampling and Preparing Minerals and Rocks before the Study of Their Chemical Compositions

Crushed rocks were processed to separate mixed fractions of olivine and clinopyroxene $0.25-0.5 \mathrm{~mm}$ and $0.5-1 \mathrm{~mm}$ across using an apparatus for separation of minerals with different densities. The mixed mineral fractions were separated into monofractions using a microscope. The resulting minerals were placed in a "compound" made of epoxy resin and diethyl phthalate. Upon solidifying, the resulting specimens were polished before being examined using $\mathrm{X}$-ray spectral microanalyzers.

The samples were prepared for subsequent analysis of major elements and accessory elements in the rocks as follows. The rocks were crushed to obtain a powder and were baked to form glass using an iridium heater.

\section{The Method Used to Determine Major and Accessory Elements in Minerals}

The analytical procedures for volcanic ejecta were performed at the Max Planck Institute for Chemistry, Mainz, Germany within the Paul Wolfgang grant for A.V. Sobolev. Essential and accessory elements in olivine, clinopyroxene, and in situ chilled glass of melt inclusions (Table 2) were determined using a Jeol JXA 8200 SuperProbe microanalyzer at the Max Planck Institute for Chemistry (Mainz, Germany). Pyroxene was analyzed using an accelerating voltage of $20 \mathrm{kV}$ and a probe current of $20 \mathrm{nA}$ with the USNM164905 in situ occurring augite reference sample (Jarosevish et al., 1980). The relative error was below $1-2$ rel. \%. Olivine was analyzed using a special technique with accuracy reaching $20-30 \mathrm{~g} / \mathrm{t}$ (two standard errors) for $\mathrm{Ni}, \mathrm{Ca}, \mathrm{Mn}, \mathrm{Al}, \mathrm{Ti}, \mathrm{Cr}$, and $\mathrm{Co}$ and $0.02 \mathrm{~mol} \%$ for $\mathrm{Mg}, \mathrm{Fe}$, and $\mathrm{Si}$, with an accelerating voltage of $20 \mathrm{kV}$ and a probe current of $300 \mathrm{nA}$ (Sobolev et al., 2007).

Accessory elements in the glasses (after being baked in an iridium heater) were analyzed using an ELEMENT-2 mass spectrometer manufactured by Thermo Scientific, England with ionization in inductively coupled plasma and laser sampling at the Max Planck Institute for Chemistry (Mainz, Germany). The error in the concentration, as estimated from reference sample reproduction, did not exceed 5 rel. \% (two standard errors) for concentrations over $1 \mathrm{~g} / \mathrm{t}$ and 10 rel. $\%$ for concentrations of approximately $0.1 \mathrm{~g} / \mathrm{t}$.

\section{THE SAMPLES}

\section{The Geological Setting and a Brief Description of the Samples}

We studied the compositions of aluminiferous basaltic andesites in cinder lapilli, of lava flows discharged during the Strombolian phase and of fragments of magnesian basalts sampled from the pyroclastic flows that were produced during the sub-Plinian phases of the 1994 Klyuchevskoi summit eruption. In addition, we studied the compositions of magnesian and aluminiferous rocks and minerals due to parasitic pre-historical eruptions, the 1938 eruptions (Bilyukai, Tiranus, and Nevidimka), and the 1966 and 1945 eruptions bearing the names of B.I. Piip and A.N. Zavaritsky, respectively; high-magnesium basalts from the nameless pre-historical parasitic vent (clinopyroxene and olivine rocks); magnesian and aluminiferous basaltic andesites discharged by the Bilyukai, Tiranus, and Nevidimka vents (plagioclase, olivine, and clinopyroxenic rocks, see Khubunaya et al., 1993); aluminiferous basaltic andesites that were discharged by the 1994 summit eruption and by the 1945 and 1966 parasitic eruptions (olivine, clinopyroxenic, and plagioclase rocks, see Ozerov and Khubunaya, 1992; Khubunaya et al., 2008). The 1994 summit eruption of Klyuchevskoi, the phases of this eruption, and its variation over time, are all described by Ozerov et al. (1996). For the ejecta of the 1994 Klyuchevskoi eruption consult (Khubunaya et al., 2008).

\section{RESULTS AND DISCUSSION}

All ejecta of the Klyuchevskoi eruptions consist of magnesian and aluminiferous basalts and basaltic andesites. The petrographic features and chemistry of the ejecta discharged by parasitic eruptions were described in detail in (Mironov et al., 2001; Ozerov and Khubunaya, 1992; Khubunaya et al., 1993, 2007). These works were the first to show that all magnesian and aluminiferous basalts and basaltic andesites involve "disequilibrium" ${ }^{1}$ associations of olivines and clinopyroxenes. These could not have been derived from melts that are in agreement with the chemical compositions of the rocks studied here. Recently, new evidence was acquired relating to the geochemistry of $\mathrm{Ca}$ and $\mathrm{Al}$ in the olivines and clinopyroxenes discharged by summit and parasitic pre-historical eruptions of Klyuchevskoi, as well as those in 1938, 1945, and 1966.

\footnotetext{
${ }^{1}$ The method employed to find equilibrium compositions of olivine and clinopyroxene at the liquidus of the magma melt was described by Khubunaya et al. (1993).
} 
Table 2. Representative analyses of in situ chilled melt inclusions and olivines (the host mineral) in cinder lapilli discharged during the Strombolian phase of the 1994 Klyuchevskoi summit eruption (wt \%)

\begin{tabular}{|c|c|c|c|c|c|c|c|c|c|c|c|c|}
\hline $\begin{array}{c}\text { Nos./Oxides, } \\
\text { elements }\end{array}$ & B1-51a & B1-33a & B1-37a & B1-36a & B1-27a & B1-42a & $\mathrm{B} 1-3 \mathrm{a}$ & B1-48a & B1-31a & B1-16a & B1-60a & B1-9b \\
\hline$\overline{\mathrm{SiO}_{2}}$ & 51.31 & 51.63 & 53.31 & 54.49 & 54.55 & 55.17 & 55.56 & 56.38 & 56.36 & 57.27 & 58.11 & 58.33 \\
\hline $\mathrm{TiO}_{2}$ & 1.18 & 1.17 & 1.17 & 1.30 & 1.36 & 1.37 & 1.43 & 1.41 & 1.47 & 1.55 & 1.50 & 1.74 \\
\hline $\mathrm{Al}_{2} \mathrm{O}_{3}$ & 18.89 & 19.13 & 17.14 & 16.41 & 16.95 & 15.75 & 16.71 & 16.38 & 16.83 & 15.06 & 15.28 & 14.73 \\
\hline $\mathrm{FeO}$ & 10.09 & 9.78 & 9.94 & 10.39 & 10.00 & 10.47 & 9.68 & 9.84 & 9.87 & 11.31 & 9.73 & 10.22 \\
\hline $\mathrm{MnO}$ & 0.14 & 0.14 & 0.19 & 0.23 & 0.19 & 0.19 & 0.18 & 0.20 & 0.22 & 0.23 & 0.17 & 0.21 \\
\hline $\mathrm{MgO}$ & 4.67 & 4.69 & 3.83 & 4.26 & 3.98 & 3.71 & 3.99 & 3.08 & 2.80 & 2.66 & 3.09 & 3.01 \\
\hline $\mathrm{CaO}$ & 8.94 & 8.91 & 10.06 & 7.90 & 7.76 & 8.32 & 7.90 & 8.14 & 7.99 & 7.14 & 7.21 & 6.84 \\
\hline $\mathrm{Na}_{2} \mathrm{O}$ & 3.39 & 3.18 & 3.04 & 3.48 & 3.63 & 3.46 & 3.00 & 3.00 & 2.90 & 3.08 & 3.01 & 2.97 \\
\hline $\mathrm{K}_{2} \mathrm{O}$ & 0.99 & 0.97 & 0.93 & 1.18 & 1.25 & 1.21 & 1.20 & 1.23 & 1.19 & 1.33 & 1.51 & 1.53 \\
\hline $\mathrm{P}_{2} \mathrm{O}_{5}$ & 0.19 & 0.20 & 0.19 & 0.24 & 0.22 & 0.24 & 0.23 & 0.23 & 0.25 & 0.26 & 0.30 & 0.33 \\
\hline $\mathrm{S}$ & 0.12 & 0.13 & 0.11 & 0.05 & 0.04 & 0.05 & 0.06 & 0.05 & 0.03 & 0.04 & 0.03 & 0.01 \\
\hline $\mathrm{Cl}$ & 0.08 & 0.08 & 0.07 & 0.07 & 0.07 & 0.07 & 0.07 & 0.07 & 0.07 & 0.07 & 0.07 & 0.08 \\
\hline $\mathrm{SiO}_{2}$ & 38.39 & 38.32 & 39.26 & 37.38 & 37.61 & 38.59 & 38.61 & 39.03 & 38.73 & 38.11 & 38.09 & 37.83 \\
\hline $\mathrm{TiO}_{2}$ & 0.02 & 0.01 & 0.01 & 0.02 & 0.02 & 0.02 & 0.01 & 0.01 & 0.02 & 0.01 & 0.02 & 0.02 \\
\hline $\mathrm{Al}_{2} \mathrm{O}_{3}$ & 0.02 & 0.02 & 0.02 & 0.02 & 0.03 & 0.02 & 0.02 & 0.02 & 0.02 & 0.02 & 0.02 & 0.02 \\
\hline $\mathrm{FeO}$ & 20.14 & 20.21 & 20.45 & 24.50 & 24.00 & 21.01 & 21.00 & 20.73 & 23.08 & 26.31 & 24.11 & 25.43 \\
\hline $\mathrm{MnO}$ & 0.32 & 0.32 & 0.33 & 0.47 & 0.46 & 0.35 & 0.34 & 0.34 & 0.43 & 0.52 & 0.46 & 0.50 \\
\hline $\mathrm{MgO}$ & 40.63 & 40.82 & 41.60 & 36.96 & 37.24 & 40.22 & 40.52 & 41.15 & 39.19 & 36.42 & 38.09 & 36.67 \\
\hline $\mathrm{CaO}$ & 0.13 & 0.13 & 0.13 & 0.23 & 0.18 & 0.15 & 0.14 & 0.13 & 0.21 & 0.22 & 0.21 & 0.21 \\
\hline $\mathrm{NiO}$ & 0.11 & 0.09 & 0.11 & 0.04 & 0.04 & 0.08 & 0.07 & 0.10 & 0.04 & 0.04 & 0.04 & 0.04 \\
\hline $\mathrm{CoO}$ & 0.03 & 0.03 & 0.03 & 0.03 & 0.03 & 0.03 & 0.03 & 0.03 & 0.03 & 0.03 & 0.03 & 0.03 \\
\hline Total & 99.80 & 99.95 & 101.94 & 99.66 & 99.61 & 100.47 & 100.74 & 101.54 & 101.75 & 101.68 & 101.07 & 100.74 \\
\hline Fo & 78 & 78 & 78 & 73 & 73 & 77 & 77 & 78 & 75 & 71 & 74 & 72 \\
\hline
\end{tabular}

$\mathrm{Fo}=\mathrm{Mg} \times 100 / \mathrm{Fe}^{2+}+\mathrm{Mg}(\mathrm{mol} \%)$. The compositions of inclusions are converted to $100 \%$ and are shown at the top of the columns.

The Crystallization of Olivine in Aluminiferous Basalticandesite Melts Discharged by the 1994 Summit Eruption and by the 1938 and 1966 Parasitic Eruptions

Phenocrysts of olivine and clinopyroxene were sampled from cinder lapilli, lava flows and lava fragments discharged by the Strombolian and sub-Plinian phases of that eruption. We investigated in situ chilled melt microinclusions that were sampled from the olivines of basaltic-andesite cinder lapilli. These are unique. The melt inclusions do not contain crystalline phases (mineral captives) and shrinkage bubbles (Fig. 1). The composition of an in situ chilled melt inclusion is a signature of the composition of the magma melt that gave rise to the olivine (host mineral). We have studied 470 olivine crystals with 40 in situ chilled glasses in melt inclusions. The chemical composition of the ejecta of the 1994 summit eruption is differentiated. The cinder lapilli and the lavas discharged during the Strombolian eruption phase are consistent with the compositions of moderate potassium high-alumina basaltic andesites (see Table 1). The lava fragments from the pyroclastic flows discharged during the subPlinian phase of the 1994 eruption have compositions of moderate potassium aluminiferous and magnesian basalts and basaltic andesites. The presence of two types of lava in the ejecta of an eruption can be interpreted as evidence pointing to a stratified magma chamber. The stratification is directly supported by the compositions of chilled glasses in melt inclusions sampled in the olivine of the cinder lapilli. The melt inclusions show differentiated compositions, ranging from high-alumina basalts to andesites (see Table 2). The geochemical bonds that have been operative in the production of basaltic andesites and andesites are obvious. The decrease in $\mathrm{CaO}$ and $\mathrm{Al}_{2} \mathrm{O}_{3}$ with increasing $\mathrm{SiO}_{2}$ in the melt is due to crystallization of $\mathrm{Pl}$ and Cpx. The olivines in the cinder lapilli were formed from a series of melts having basaltic, basaltic andesite, and andesite compositions (Fig. 2). This cannot occur unless there is a magma chamber where the melt could reside under equilibrium conditions. The fact that the chamber is shallow is supported because $\mathrm{S}$ and 

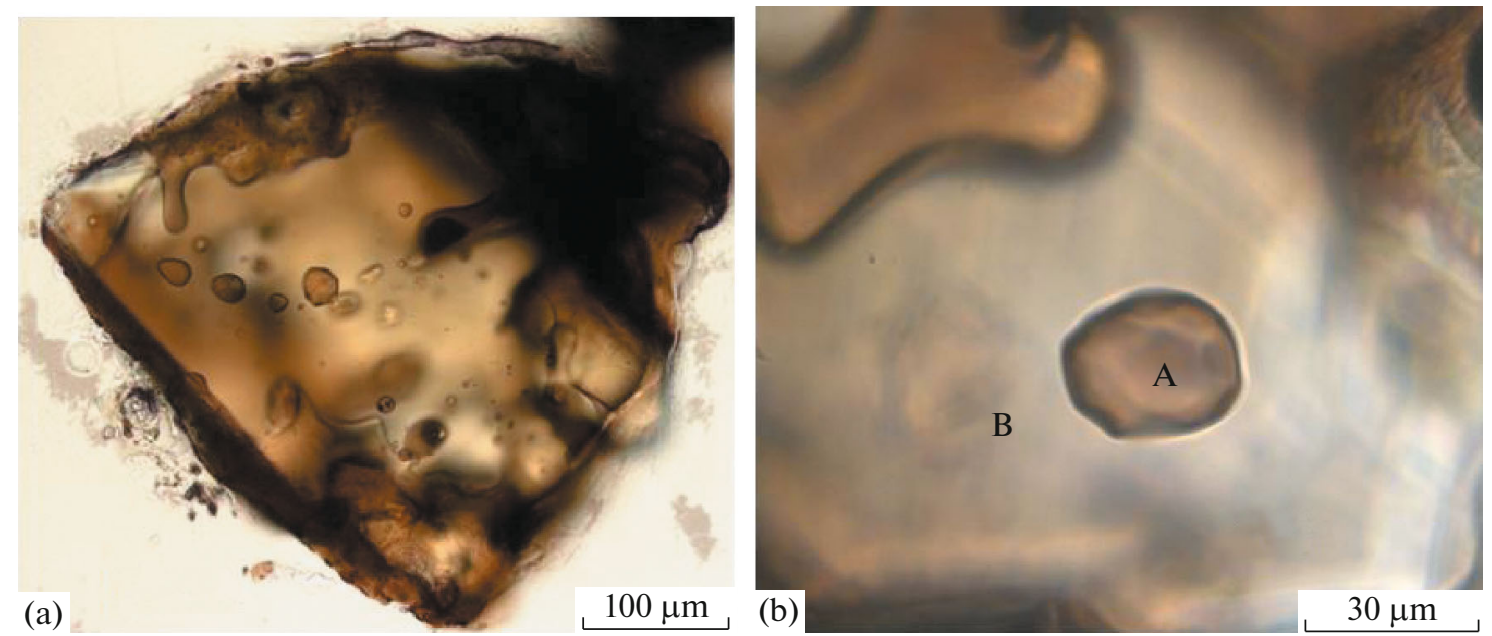

Fig. 1. A microphotograph of in situ chilled glasses in melt inclusions found in the olivine of the cinder lapilli discharged during the 1994 summit eruption of Klyuchevskoi. (a) olivine (host mineral) with in situ chilled melt inclusions; (b) an enlarged part of olivine (host mineral): (A) glass of in situ chilled melt inclusions, (B) olivine (host mineral).

$\mathrm{Cl}$ are intensively degassed (see Figs. 2b, 2d). The lowest degassing of $\mathrm{S}$ and $\mathrm{Cl}$ compositions is observed in basaltic melt inclusions, while the highest degassing occurs in andesitic melt inclusions. This circumstance may indicate the location of the andesitic melt in the magma chamber, viz., in its upper, apical part. One observes a quite paradoxical fact that consists in the behavior of $\mathrm{CaO}$ in the olivine of aluminiferous melts from which they crystallized in the hypothetical magma chamber. As the magnesium number decreases in the melt during olivine crystallization, the concentration of $\mathrm{CaO}$ in the olivines that had crystallized from basaltic, basaltic andesite, and andesitic melts, increases (Fig. 3a), while the concentration of $\mathrm{CaO}$ in melt inclusions rapidly decreases (see Fig. 3b). The paradox of this situation consists in the fact that plagioclase crystallizes at the liquidus of aluminiferous melts of moderate potassium basaltic andesites as deduced from petrographic analyses (Zavaritsky, 1931; Ozerov and Khubunaya, 1992; Khubunaya et al., 2008). Further crystallization of olivines occurred in the cotectic $\mathrm{Mt}-\mathrm{Ol}-\mathrm{Cpx}-\mathrm{Pl}$ mode. The crystallization of $\mathrm{Cpx}$ and $\mathrm{Pl}$ reduced the concentration of $\mathrm{CaO}$ in the residual melt of the magma chamber (see Fig. 3b). At the same time, the concentration of $\mathrm{CaO}$ in the olivines that had crystallized from the melt must decrease as well, while the actual tendency is exactly the opposite, namely, the concentration of $\mathrm{CaO}$ in olivine increases as their magnesium number decreases (see Fig. 3a). A similar increase in $\mathrm{CaO}$ concentration in olivine with the magnesium number increasing has been observed for aluminiferous basaltic andesites found in the 1994 cinder lapilli and lava flows (Fig. 4a). A similar variation in the concentration of $\mathrm{CaO}$ for some olivines combined with a decreasing magnesium number during crystallization is found in the basaltic andesites discharged by the
1938 and 1966 eruptions (see Figs. 4b, 4c). An explanation of this effect can be found in several studies in the solubility of $\mathrm{CaO}$ in olivine during crystallization under a variety of physical and chemical conditions. The increased concentration of $\mathrm{CaO}$ in $\mathrm{Ol}$ can be due to a decrease in the crystallization pressure for $\mathrm{Ol}$ in the presence of $\mathrm{H}_{2} \mathrm{O}$. Stormer (1973) noted that an increasing concentration of $\mathrm{CaO}$ in olivine combined with a concomitant decrease in the crystallization temperature in the residual melt indicates that the melt was formed under decreasing pressure, i.e., as the magma was rising. Subsequent experiments in the presence of water revealed a significant effect exerted by the concentration of water in the melt on the distribution of $\mathrm{Ca}$ (Feig et al., 2006). Gavrilenko et al. (2016) analyzed experimental and field data and proposed some analytical relationships for estimating the effect of water on the partitioning coefficient of calcium between olivine and melt. These results showed that increasing the concentration of water in a melt reduces the concentration of $\mathrm{Ca}$ in olivine. From this it follows that the effect of pressure on the distribution of $\mathrm{Ca}$ is to reduc the concentration of $\mathrm{H}_{2} \mathrm{O}$ during degassing of the magma as it is rising from the magma chamber. High concentrations of water (up to $2.9 \mathrm{wt}$ $\%$ ) in the parent magmas of Klyuchevskoi Volcano were first detected by Khubunaya and Sobolev (1998) and Sobolev and Chaussidon (1996), among others. It should be noted that the fragments of magnesian basalt in the pyroclastic flow due to the 1994 sub-Plinian summit eruption took no part in partitioning the aluminiferous melts, being probably torn from the bottom or walls of the hypothetical magma chamber.

One finds two sets of olivines in the same sample taken from the aluminiferous basaltic andesites discharged by the 1938 and 1966 parasitic eruptions (see Figs. $4 b, 4 c)$. In one of these sets the concentration of 



Fig. 2. The compositions of in situ chilled glasses in melt inclusions sampled from olivine (host mineral) phenocrysts of the cinder lapilli discharged during the 1994 summit eruption of Klyuchevskoi.(1) basalts; (2) basaltic andesites; (3) andesites. $R^{2}$ is a measure of the fit significance. The arrow indicates the direction of change in glass compositions of in situ chilled melt inclusions.

$\mathrm{CaO}$ in olivine increases as the olivine magnesium number of the decreases from $\mathrm{Fo}_{80}$ to $\mathrm{Fo}_{70}$. The tendency of increasing concentrations of $\mathrm{CaO}$ in the olivines of basaltic andesites during crystallization is the same as that observed in the olivines of aluminiferous basaltic andesites due to the 1994 summit eruption (see Fig. 4a). In addition, the 1945 and 1966 lavas have compositions like those of high-alumina basaltic andesites (see Table 1). This set of olivines obviously crystallized from a high-alumina magma. The concentration of $\mathrm{CaO}$ in olivines in the other, larger set of $\mathrm{Fo}_{90-80}$ olivines from the same sample slowly decreases as their magnesium number decreases (see Figs. $4 \mathrm{~b}, 4 \mathrm{c}$ ). This behavior of $\mathrm{CaO}$ during the crystallization of olivine is observed in the magnesian basalts that were discharged by the nameless prehistorical eruption and in fragments of the pyroclastic flows discharged by the 1994 summit eruption (see Figs. 4a, 4d). Although these high-magnesium olivines $\left(\mathrm{Fo}_{90-80}\right)$ are present in samples of high-alumina basaltic andesites, they were formed from a magnesian magma. The amount of olivine crystals from an aluminiferous magma is significantly below that of olivines that were formed from magnesian melts (see Figs. 4b, 4c). This is due to the sampling procedure. The samples from the 1938 and 1966 basaltic andesites were taken at the sources of the lava flows where high-magnesium "disequilibrium" olivines and clinopyroxenes predominate over the amount of "equilibrium" minerals.

\section{Olivine Crystallization in the Magnesian Moderate Potassium Basalts Discharged by the Parasitic Eruptions of Klyuchevskoi}

The crystallization of basalts produced by the highest-magnesium "nameless" vent resulted in $\mathrm{Fo}_{93}$ olivine (see Fig. 4d). The concentration of $\mathrm{CaO}$ in olivines increases by $300 \%$, as the magma was rising in the deeper magma chamber, while their magnesium number remains nearly constant. It was only when highmagnesium clinopyroxene appeared that the magnesium number of olivine decreased from $\mathrm{Fo}_{90}$ to $\mathrm{Fo}_{80}$. The $\mathrm{Fo}_{93-92}$ olivine was ascending from the primary picrite magma at the lowest temperature $\left(1280^{\circ} \mathrm{C}\right)$, a pressure of about $18 \mathrm{kbars}$, and in the presence of $\mathrm{H}_{2} \mathrm{O}$ (approximately 2.9\%) in the deeper magnesian chamber (Khubunaya and Sobolev, 1998; Khubunaya et al., 2007, among others). The olivines showed nearly no change in their magnesium number with a simultaneous increase in $\mathrm{CaO}$, providing evidence of the fact that the olivines in the deeper chamber crystallized without clinopyroxene at the liquidus. Otherwise, the variation in the magnesium number of olivines would have been far from vertical (see Fig. 4d). If olivines and clinopyroxenes had crystallized together at a decreasing pressure, one would have observed the magnesium number of the olivines vary, dipping toward $\mathrm{CaO}$, as is the case during cotectic crystallization of olivines and clinopyroxenes in aluminiferous melts at a decreasing pressure (see Figs. 4a, 4b, 4c). It was only when the concentration of $\mathrm{CaO}$ in olivines reached 0.15 (wt \%) that the olivines and clinopyroxenes began to undergo 
cotectic crystallization, which lasted an indefinite time with a concomitant considerable decrease in the olivine magnesium number, from $\mathrm{Fo}_{90}$ to $\mathrm{Fo}_{80}$ (see Fig. 4d). This tendency to a slow decrease in the concentrations of $\mathrm{CaO}$ in olivines accompanied by a considerable decrease of their magnesium number from $\mathrm{Fo}_{90}$ to $\mathrm{Fo}_{80}$ is found in magnesian basalts sampled from fragments in the 1994 pyroclastic flow (see Fig. 4a). A similar slight decrease in $\mathrm{CaO}$ during olivine crystallization is found for some olivines discharged by the 1938 and 1966 parasitic eruptions (see Figs. 4b, 4c). According to a numerical simulation using the PETROLOG program for an olivine-melt system and petrographic analysis, such olivines also crystallized from magnesian melts in the cotectic $\mathrm{Sp}-\mathrm{Ol}-\mathrm{px}$ mode (Khubunaya et al., 1993, 2008). The considerable (up to $300 \%$ ) increase in the concentration of $\mathrm{CaO}$ in the olivines of the highest-magnesium "nameless" flow was related to the magma ascending during its crystallization in the deeper magma chamber (see Table 1). An inconsiderable decrease in $\mathrm{CaO}$ in olivines with a large simultaneous decrease in magnesium number may indicate a crystallization that was due to decreasing temperature at a stable pressure. As mentioned above, the concentration of $\mathrm{CaO}$ in olivines slightly decreases during the cooling of the melt at a constant pressure. As magma rises during crystallization and $\mathrm{H}_{2} \mathrm{O}$ is degassed the concentration of $\mathrm{CaO}$ in olivines increases.

The presence of two sets of olivines with opposite behaviors of $\mathrm{CaO}$ during crystallization is found in the ejecta of all parasitic aluminiferous eruptions of Klyuchevskoi (Ozerov and Khubunaya, 1992; Khubunaya et al., 2008). The most plausible explanation of this phenomenon is that the crystallization occurred under different physico-chemical conditions, hence in different magma chambers. The Fo $_{90-80}$ olivines crystallized at a decreasing temperature and a stable pressure from a magnesian magma in the deeper chamber in the cotectic $\mathrm{Sp}-\mathrm{Cpx}-\mathrm{Ol}$ mode (Khubunaya et al., 1993, 2007). The other set of olivines (with $\mathrm{Fo}_{80-70}$ ) crystallized in a shallow aluminiferous stratified chamber in the cotectic $\mathrm{Mt}-\mathrm{Ol}-\mathrm{Cpx}-\mathrm{Pl}$ mode. The presence of the two sets of olivines in a single sample and in the same lava flow of aluminiferous basaltic andesites with different geochemical behaviors of $\mathrm{CaO}$ during the crystallization is due to the emplacement of magnesian magmas into the shallow magma chamber. The emplacement and the subsequent mixing of magnesian and aluminiferous magmas could have been occurring during the eruption itself.

\section{The Crystallization of Clinopyroxenes from Different Magma Chambers}

The olivines crystallized from different magma chambers, as can be inferred from different variations in the concentration of $\mathrm{Al}_{2} \mathrm{O}_{3}$ in clinopyroxenes during

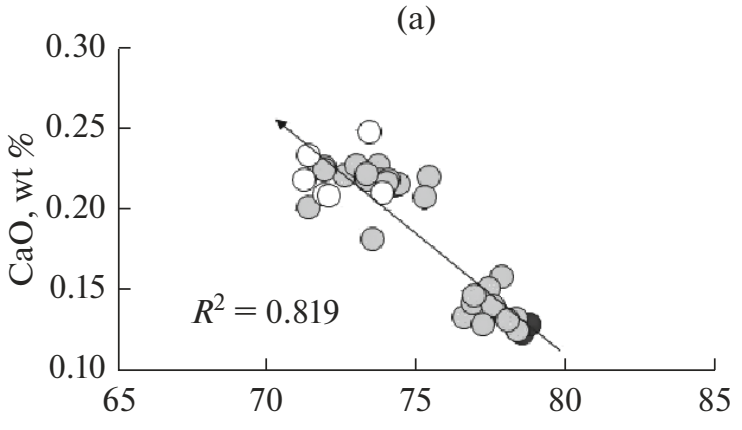

(b)

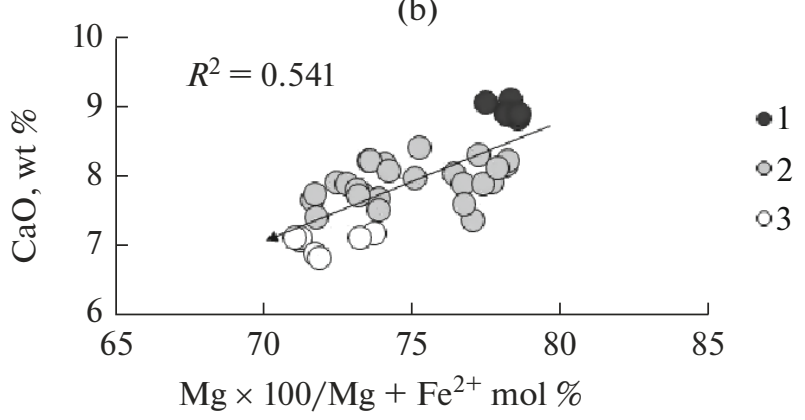

Fig. 3. The concentrations of $\mathrm{CaO}$ in olivine (host mineral) and in the in situ chilled glasses of melt inclusions found in cinder lapilli discharged by the 1994 Klyuchevskoi eruption. (a) olivine (host mineral); (b) in situ chilled glasses of melt inclusions. The arrow indicates the direction of change for the compositions of olivine and glass in the in situ chilled melt inclusions. For the legend see Fig. 2.

crystallization. Two sets of clinopyroxenes are found in the 1945, 1953, 1966, and 1938 parasitic eruptions of aluminiferous basaltic andesites (Fig. 5). The concentration of $\mathrm{Al}_{2} \mathrm{O}_{3}$ constantly increases (up to 6-7\%) in the one set of clinopyroxenes, as their magnesium number decreases from $\mathrm{Mg} \# 90$ to $\mathrm{Mg} \# 80-75$ during crystallization, while in the other set of clinopyroxenes, in the same lava flow and in the same sample, the concentration of $\mathrm{Al}_{2} \mathrm{O}_{3}$ rapidly decreases to reach 1-2\% after $\mathrm{Mg} \# 80-75$ (see Fig. 5). The continuous trend of clinopyroxenes being enriched in $\mathrm{Al}_{2} \mathrm{O}_{3}$ coupled with their magnesium number decreasing from $\mathrm{Mg} \# 90$ to $\mathrm{Mg} \# 80-75$ was due to the crystallization of $\mathrm{Cpx}$ and $\mathrm{Ol}$ in the cotectic $\mathrm{Sp}-\mathrm{Cpx}-\mathrm{Ol}$ mode in the deeper magnesian chamber beneath Klyuchevskoi. These clinopyroxenes were emplaced into the shallow aluminiferous chamber beneath the volcano along with the magnesium-rich melt and the $\mathrm{Fo}_{90-80}$ olivines described above. The clinopyroxenes in which the concentration of $\mathrm{Al}_{2} \mathrm{O}_{3}$ is decreasing together with a decreasing magnesium number crystallized from an aluminiferous magma following the cotectic $\mathrm{Mt}-\mathrm{Ol}-$ $\mathrm{Cpx}-\mathrm{Pl}$ mode in the shallow chamber. The crystallization of plagioclase and of clinopyroxenes (this to a lesser degree) led to depletion of the residual melt in $\mathrm{Al}_{2} \mathrm{O}_{3}$. Clinopyroxenes with magnesium numbers 
(a)

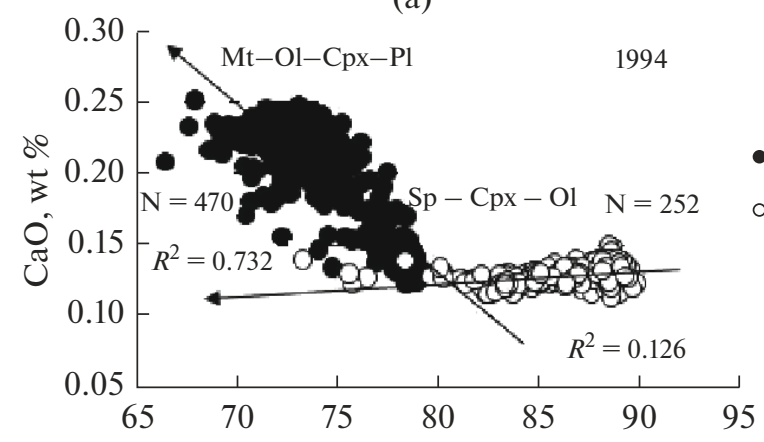

(c)

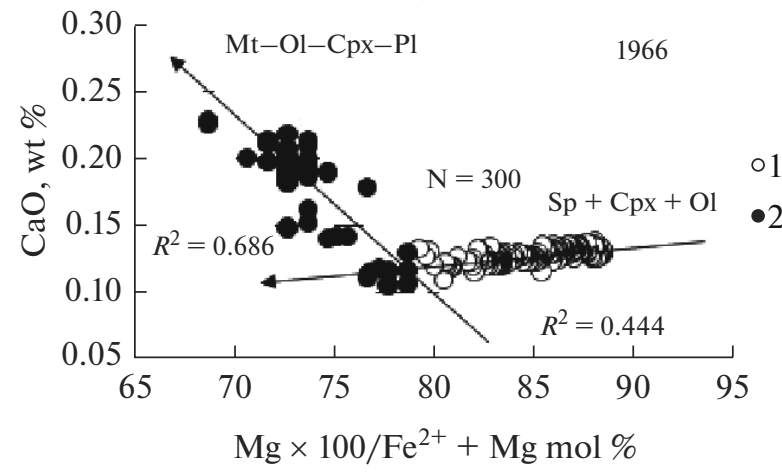

(b)

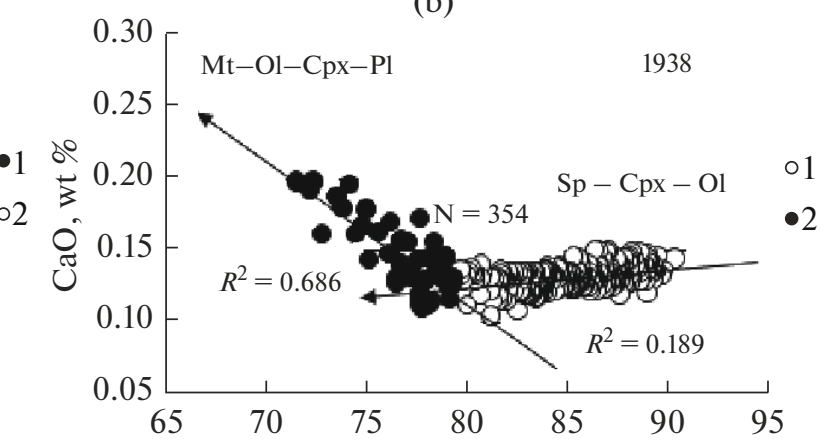

(d)

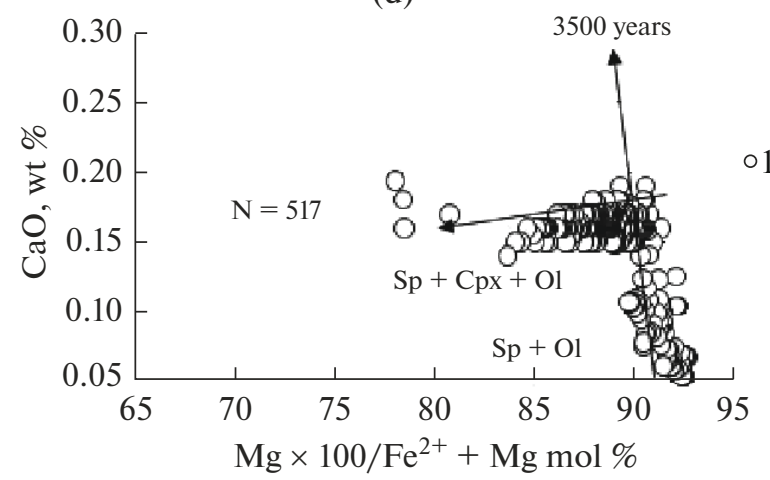

Fig. 4. The compositions of olivine in moderate potassium high-alumina and magnesian basalts and basaltic andesites erupted by Klyuchevskoi. (a) 1994 summit eruption: (1) olivine in aluminiferous basaltic andesites found in cinder lapilli, (2) olivines in magnesian basalts sampled from fragments of the pyroclastic flow in the Apakhonchich chute; (b) olivine in magnesian basaltic andesites discharged by the Bilyukai cone (the 1938 parasitic eruption): (1) olivine in hypothetical magnesian magmas, (2) olivine in hypothetical aluminiferous magmas; (c) olivine in aluminiferous basaltic andesites sampled from the lava flow of the 1966 parasitic eruption: (1) olivine in hypothetical magnesian magmas, (2) olivine in hypothetical aluminiferous magmas; (d) olivine in magnesian basalts discharged by the prehistorical nameless eruption: (1) olivine in magnesian magmas of the deeper chamber. $\mathrm{N}$ denotes the number of olivine analyses; Mt, Sp, Ol, Cpx, and Pl stand for magnetite, spinel, olivine, clinopyroxene, and plagioclase, respectively; $\mathrm{R}^{2}$ denotes a measure of the significance of the fit. The arrow indicates the direction of change for olivine composition.

below Mg\#80-75 crystallized from this residual melt. This is corroborated by two sets of clinopyroxenes with different concentrations of $\mathrm{Al}_{2} \mathrm{O}_{3}$, but with the same magnesium number (see Fig. 5). They crystallized from magnesian and aluminiferous magmas under different physico-chemical conditions and in different magma chambers.

The most likely scenario for the Klyuchevskoi parasitic eruptions seems to be as follows. A magnesian magma along with clinopyroxenes and $\mathrm{Fo}_{90-80}$ olivines was emplaced from a deeper chamber (Gontovaya et al., 2011; Khubunaya et al., 2007; Kulakov et al., 2016, among others) and was discharged onto the ground surface along with its material. For this reason the ejecta of all parasitic moderate potassium aluminiferous basaltic andesite eruptions contain "disequilibrium" high-magnesium clinopyroxenes and $\mathrm{Fo}_{90-88}$ olivines that are typical of mantle melts. That this model is plausible is corroborated by observations of enrichment in high-magnesium $\mathrm{Ol}$ and $\mathrm{Cpx}$ (up to 9\% of the rock volume) for the ultimate portions of flows of moderate potassium aluminiferous basaltic andesites discharged by the 1966 and 1945 eruptions (Vazheevskaya, 1972; Piip, 1956). Plagioclase is also involved in the gravitational partitioning of minerals in the intermediate chamber beneath the volcano. The lava flow of aluminiferous basaltic andesites discharged by the 1966 eruption was found (at the start of the eruption) to contain increased amounts of plagioclase and it was only nearer the end of the eruption that the lava was strongly enriched in high-magnesium olivines and pyroxenes (Vazheevskaya, 1972). A support for the gravitational crystallization stratification in the shallow magma chamber can be found in the presence of numerous leucocratic and melanocratic homogeneous inclusions in lava fragments that occur in the pyroclastic flow of aluminiferous basaltic andesites discharged by the 1994 eruption. The existence of a shallow magma chamber beneath the Klyuchevskoi volcanic edifice is also corroborated by other parameters of the Klyuchevskoi eruptions, namely, considerable volumes of volcanic ejecta from the 1937-1938 eruption and the sequence of ejecta 

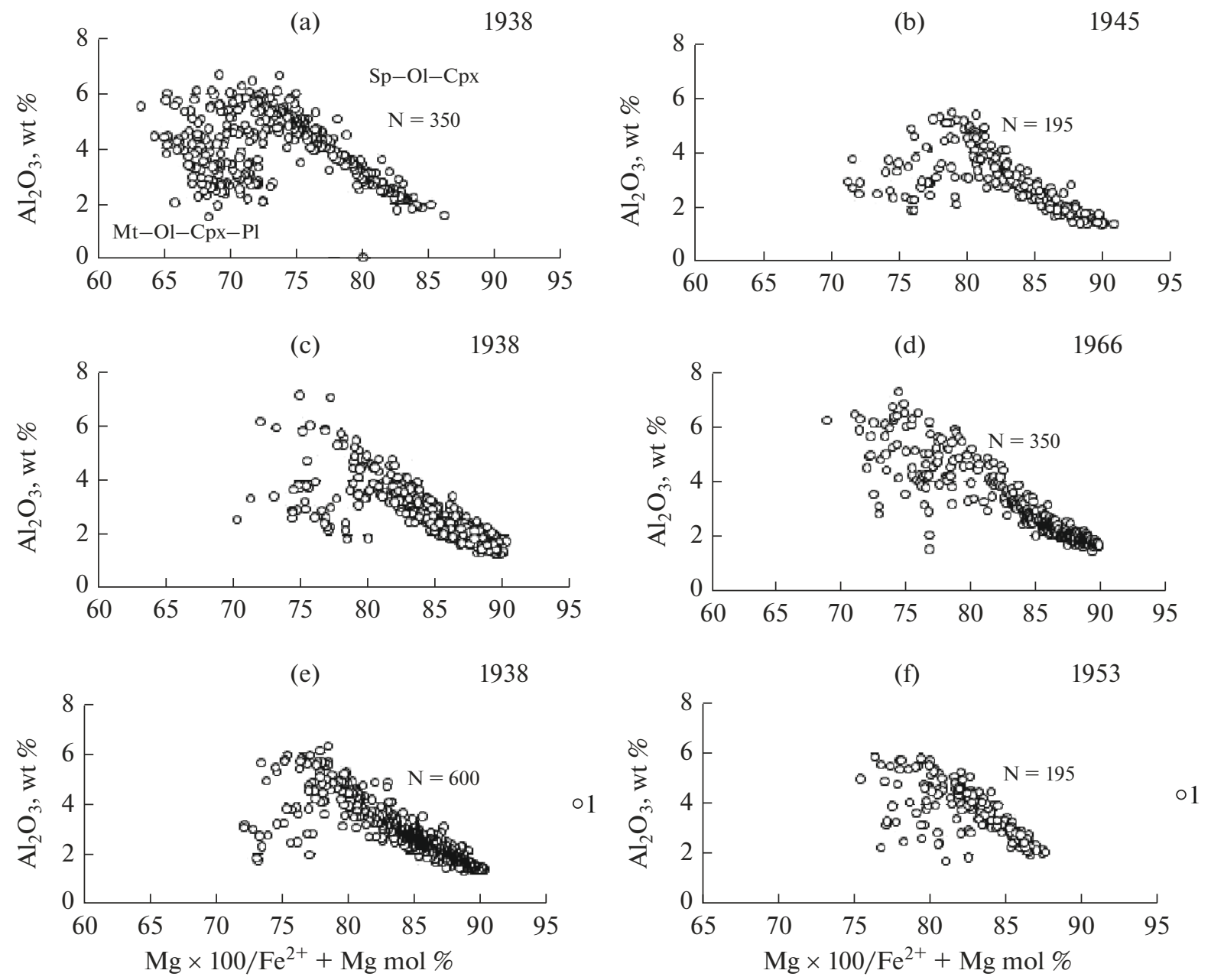

Fig. 5. The compositions of clinopyroxenes in basaltic andesites of lava flows discharged by parasitic eruptions of Klyuchevskoi. (a) Aluminiferous basaltic andesites in the Nevidimka lava flow; (b) aluminiferous basaltic andesites sampled from the Zavaritsky lava flow; (c) magnesian basaltic andesites sampled from the Tiranus lava flow; (d) aluminiferous basaltic andesites sampled from the Piip lava flow; (e) magnesian basaltic andesites discharged by the Bilyukai cone; (f) aluminiferous basaltic andesites sampled from the Belyankin lava flow. (1) Clinopyroxenes from hypothetical high-alumina magmas; (2) clinopyroxenes from hypothetical magnesian magmas; $\mathrm{N}$ denotes the number of analyses of clinopyroxene.

from this eruption lasting as long as 2 years (Menyailov, 1947). Magma rose from the stratified shallow chamber along a dike that was striking northeast. The upper part of this dike consisted of a "plume" of aluminiferous basaltic andesite magma, while the lower part consisted of aluminiferous magmas that were already saturated with high-magnesium crystals of olivine and pyroxene resulting from the emplacement of magnesian magma from a deeper chamber (see Figs. 4b, 5a, 5c, 5e). The mineralogic features of the aluminiferous basaltic andesites discharged by the 1945, 1966, and 1953 parasitic eruptions, as well as by the 1938 eruption (Bilyukai, Tiranus, and Nevidimka), provide evidence of the mixing of moderate potassium magnesian and aluminiferous magmas coming from different magma chambers during parasitic Klyuchevskoi eruptions.

\section{Changes in Olivine Compositions in Klyuchevskoi Melts Dependent on Temperature and Pressure}

The present study is not concerned with the genesis of the aluminiferous magmas. Nevertheless, the results for the solubility of $\mathrm{CaO}$ in olivines during crystallization in magnesian and aluminiferous magmas throw some light on certain tenets in the hypothesis relating to the genesis of aluminiferous magmas during a decompression mode of crystallization (Ariskin et al., 1995). Two circumstances serve as important supplements to the above hypothesis. The crystallization of magnesian magma starts as olivine is released in the presence of spinel rather than as olivine and pyroxene are released in the presence of spinel, as was previously thought (Ariskin et al., 1995). The polybaric crystallization of olivines and pyroxenes stops for an indefinite time. The crystallization was probably occurring in the upper horizons of a deeper magma chamber under 


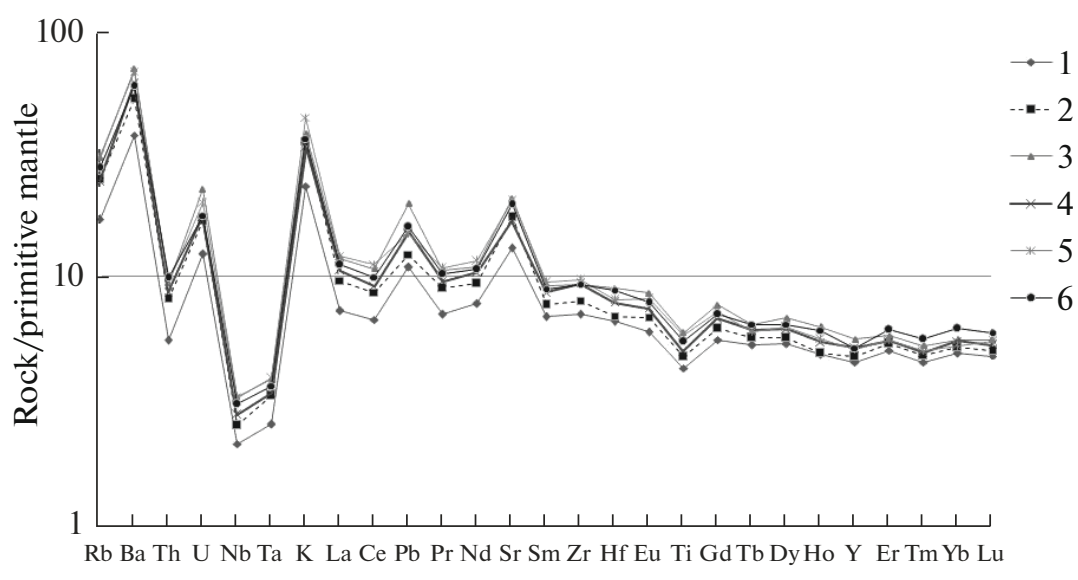

Fig. 6. The distribution of incoherent elements in moderate potassium magnesian and high-alumina basalts and basaltic andesites discharged by Klyuchevskoi. (1) magnesian basalt sampled from a volcanic bomb ejected by the prehistorical nameless eruption; (2) magnesian basaltic andesite discharged by the Bilyukai cone; (3) aluminiferous basaltic andesite sampled from cinder lapilli discharged by the 1994 summit eruption; (4) aluminiferous basaltic andesite sampled from the 1994 lava flow; (5) aluminiferous basaltic andesite sampled from the 1966 lava flow; (6) aluminiferous basaltic andesite sampled from the 1945 lava flow. The concentrations of accessory elements in rocks $(\mathrm{g} / \mathrm{t})$ have been normalized by the respective concentrations in the primitive mantle after (Hoffman, 1988).

quiet conditions accompanied by decreasing temperature, but without any pressure changes (see Fig. 4d). Further decompressional crystallization of magnesian magma occurred during its emplacement into a highalumina shallow chamber. The authors of the present report have studied thousands of clinopyroxene and olivine crystals in magnesian and aluminiferous basalts and basaltic andesite by separating minerals with different densities using bromoform. The result was to find that orthopyroxene is encountered very rarely among phenocrysts, below $1 \%$ (Khubunaya et al., 1993, 2008). The highest concentration of $\mathrm{SiO}_{2}$ in Opx did not exceed 54\%. Ariskin et al. (1995) pointed out that orthopyroxene does not exert any significant effect on the lines of cotectic control.

\section{The Geochemical Features of Moderate Potassium Magnesian and Aluminiferous Basalts and Basaltic Andesites Discharged by Klyuchevskoi}

Although moderate potassium magnesian and aluminiferous magmas reside in different magma chambers they come from the same mantle source (Khubunaya et al., 2016).

The Klyuchevskoi rocks that are compared using a multicomponent diagram (a spider diagram) that shows the distributions of incoherent elements show similar configurations of all data points due to accessory elements. They have deep minima in the spider diagram for high-charge elements $(\mathrm{Th}, \mathrm{Nb}$, and $\mathrm{Ti})$ and maxima for large ion lithofile elements ( $\mathrm{Ba}, \mathrm{K}, \mathrm{Sr}$, and $\mathrm{Pb}$ ), as well as for $\mathrm{U}$ (Fig. 6). They exhibit the most characteristic feature of all moderate potassium island arc basalts and basaltic andesites. A well-pronounced $\mathrm{Sr}$ maximum is found both for the highest- magnesium basalts discharged by the prehistorical "nameless" vent and for the highest-alumina basaltic andesites due to the 1994 eruption (see Fig. 6).

The petrologic arguments in favor of crustal magma chambers beneath Klyuchevskoi are quite consistent with data acquired through geophysical methods (explosion and earthquake seismology, geoelectricity, and gravity surveys). The focus in the present paper is on seismology.

Deep seismic sounding and refraction surveys were carried out to study the crust beneath the Klyuchevskoi Volcanic Cluster (KVC) in the 1970-1990s (Anosov et al., 1978; Balesta et al., 1991). They were concerned with the study of deep structure and with identification of magma chambers as part of the plumbing system in the area. This goal has only partially been reached owing to the sparsity of the observational network and methodological difficulties in the study of heterogeneous media. Nevertheless, data have been acquired that bear on the major discontinuities in the crust, their morphology, and velocity properties. According to the deep seismic sounding survey, the crustal thickness beneath the volcanic cluster was found to be at $30-40 \mathrm{~km}$, while the Moho seemed to be stratified. Unilateral seismic probing of the cluster (from a single source) revealed an anomalous attenuation of compressional (P) waves beneath Klyuchevskoi. The character of the phase structure was sufficient to tentatively identify a magma chamber that supplies Klyuchevskoi, approximately at the Moho depth (Anosov et al., 1978). No evidence has been obtained for any intermediate magma chambers in the crust beneath the volcano. The observational system was insufficient to study the problem. The 1990s saw seismic observations (using $\mathrm{P}$ waves) along a refraction 
line that intersected the Klyuchevskoi volcanic cone running SW-NE along a deep-seated fault near the volcanic cluster (Balesta et al., 1991). It was found that the crystalline basement under the cluster involves a depression and that there is a contrasted asymmetry in the upper crustal velocity structure. The uplifted southwestern block has higher velocities and a homogeneous internal structure. The upper crust involves lower velocities beneath the northeastern slope of the volcano where most parasitic cones are situated. The crust consists of layers with relatively higher and lower compressional velocities. Compressional waves alone cannot resolve the genesis of such a structure well. It can be interpreted as interbeds of sedimentary-volcanogenic rocks overlain by a mass of cooled effusive rocks that contain melt-fluid inclusions which form the low velocity layers. However, the overall crustal velocity structure beneath the volcanic cone suggests that the higher velocity block beneath the southwestern slope must be related to a hypothetical older magma chamber beneath Kamen' Volcano. The lowvelocity block, in the depressed part of the crystalline basement, is thought to be related to the present-day shallow magma chamber at a depth of approximately 5-6 km (Piip et al., 1991; Khubunaya et al., 2007). It should be noted that the occurrence of shallow chambers at depressions of the crystalline basement is characteristic for many volcanoes worldwide, e.g., Etna, Vesuvius, St. Helens, Rabaul, and many others.

Active tectono-magmatic processes are occurring in the Klyuchevskoi area; these processes are accompanied by a high seismicity and well-pronounced patterns in seismicity distribution in the crust beneath the volcanoes. We will examine a $2-\mathrm{D}$ distribution of the $\mathrm{b}$-value in the depth range $0-35 \mathrm{~km}$ beneath the volcanic cluster. The $b$-values (the slope of the frequency-magnitude distribution of earthquakes) were calculated from the catalog due to the Kamchatka Branch of the Federal Research Center (FRC) of the Unified Geophysical Survey (UGS) of the Russian Academy of Sciences (RAS) for the 1999-2005 period. A total of $12500 M \geq 1.6$ events was used (L.I. Gontovaya and N.A. Kozyreva, personal communication). Anomalies of that parameter may indicate zones of higher cracking and/or higher pore pressure. They may also be related to magma chambers (Wiemer and McNutt, 1997, among others). An intensive b-value anomaly is found to reside beneath Klyuchevskoi Volcano in the depth range $\sim 27-34 \mathrm{~km}$, gradually rising to reach $18-20 \mathrm{~km}$ (Fig. 7). This figure shows the net effect due to seismicity, as well as the shape and volumes of the host rocks that are involved in failure and in the evolution of magma (Ermakov et al., 2014). The distribution of the parameter thus provides evidence in favor of a magma chamber in the lower crust (or not deeper than the Moho) beneath Klyuchevskoi Volcano.

The last decade saw wide use of seismic tomography to study the 3-D crustal structure beneath the
KVC based on travel times of compressional (P) and shear (S) waves excited by volcano-tectonic earthquakes at recording stations of the Kamchatka network operated by the Kamchatka Branch of the FRC GS RAS. The spatial distribution of seismic velocity anomalies (Vp, Vs, and the $\mathrm{Vp} / \mathrm{Vs}$ ratio) provides data from which to draw our knowledge of deep crustal structure and to identify anomalous zones that could be related to magma chambers beneath the KVC. These are thought to be responsible for intensive negative anomalies, in particular, in Vs, and higher values of Vp/Vs. The intensity of such anomalies must obviously be largely dependent on the model that we choose to employ to calculate velocity anomalies. Several crustal velocity models are available for the KVC area based on observations of VT earthquakes (Gontovaya et al., 2004; Ermakov et al., 2014; Koulakov et al., 2013; Ivanov et al., 2016, among others). The models are generally similar among themselves, but also show some differences. These differences are due to the choice of the data set, changes in network configuration, as improvements are introduced over time, to the inversion algorithms, and several other factors. Here, we are going to discuss a result acquired by a combined effort on the part of the Institute of Volcanology and Seismology (IV\&S) of the Far East Branch (FEB) RAS and the Institute of Geosphere Dynamics, RAS using methods and algorithms developed at the University of Zurich, Switzerland. Figure 8 illustrates vertical sections of a 3-D crustal velocity model in $\mathrm{Vp}$ and Vs anomalies. The section is along the refraction line and the 2-D picture of the $\mathrm{b}$-values as discussed above. The plane of the section also shows velocity anomalies and the hypocenters of VT earthquakes from bands $5 \mathrm{~km}$ wide on both sides of the section. There are intensive anomalies in Vp and Vs in the near-summit part of the volcanic cone and along its northeastern periphery. The values of the negative Vs anomaly are in the $6-15 \%$ range within that zone, which can be due to fluid/melt inclusions. The maximum thickness of the anomalous zone is approximately $3 \mathrm{~km}$ and the length is $12-14 \mathrm{~km}$. The anomalous zone has the shape of a sill. It contains most of the parasitic cones on the volcano's northeastern slope. An intensive negative anomaly in $\mathrm{Vp}$ and $\mathrm{Vs}$ was found to exist at the base of the volcano's cone (at $1800 \mathrm{~m}$ ). The region as here identified is not inconsistent with gravity and refraction data (Zubin et al., 1990; Balesta et al., 1991; Piip et al., 1991) and furnishes additional arguments in favor of an existing shallow source or several magma chambers within the anomaly. Refraction data argue for the source to be situated between the folded unit and the top of the consolidated basement (Balesta et al., 1991). Overall, the region is in agreement with the characteristics predicted by B.I. Piip from geological data. These characteristics incorporated the thickness and character of the sedimentary features and the compositions of the xenoliths that were captured by magma during Klyuchevskoi eruptions (Piip, 1956). 


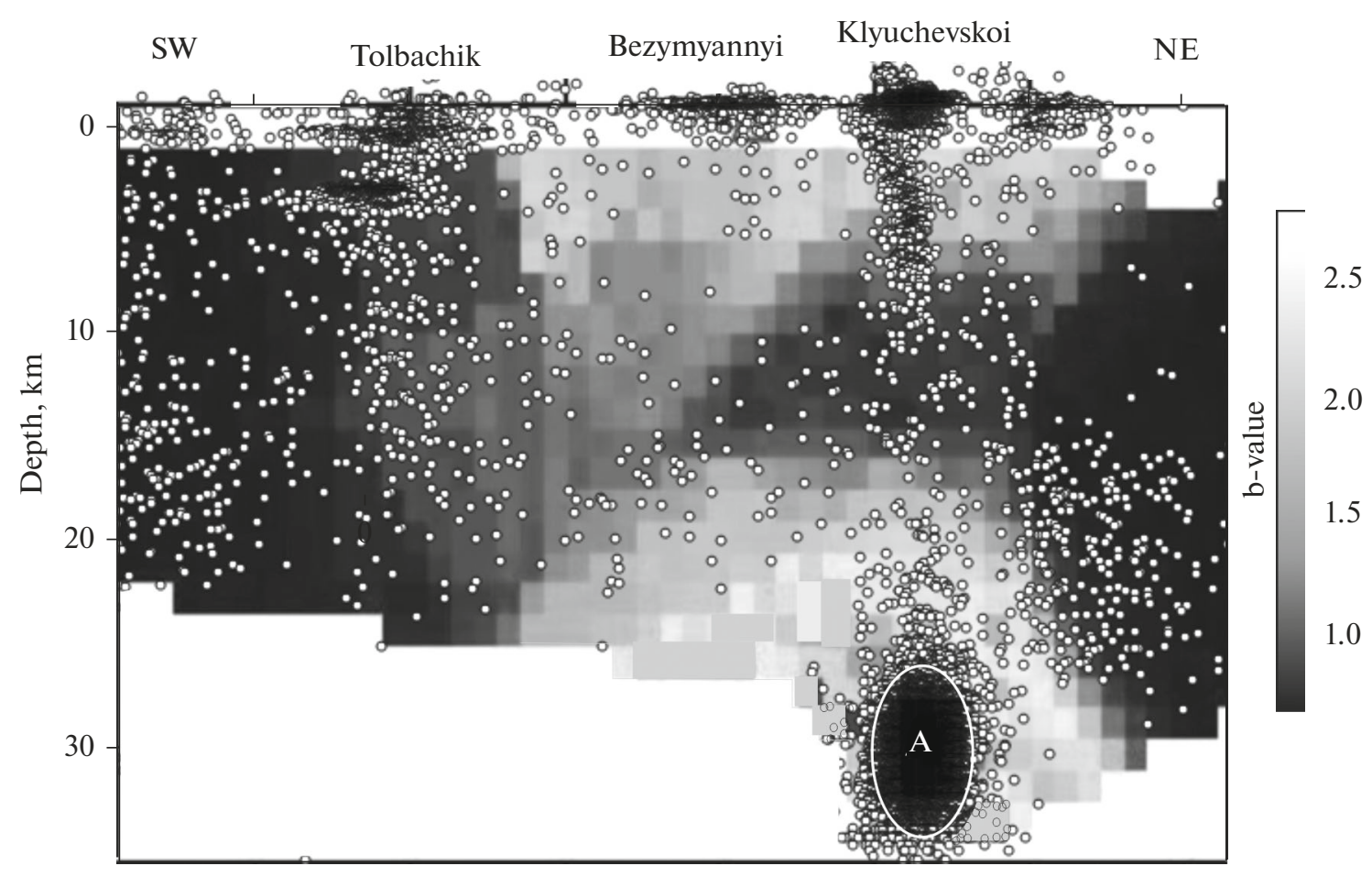

Fig. 7. A 2-D image of frequency-magnitude distributions for volcano-tectonic earthquakes (the b-value) beneath the volcanoes of the Klyuchevskoi Volcanic Cluster. The white dots represent earthquake hypocenters; the white line encloses region A where deep-focus long-period earthquakes (DFLP) are the densest. The numerals in the right part of this figure denote b-values.

According to Koulakov et al. (2013) and Ivanov et al. (2016), an isometric anomaly of higher Vp/Vs exists at a depth of approximately $10 \mathrm{~km}$ beneath the Klyuchevskoi cone. The anomaly can be related to a shallow magma chamber at the base of the crystalline basement depression beneath the KVC.

The most-pronounced velocity anomaly is in a lower crustal zone at depths of 25-35 km (see Fig. 8). It is seen in all crustal velocity models for the KVC as developed by various authors based on the KB GS RAS catalog of VT earthquakes. The anomaly is clearly seen in the b-value field where an intensive cluster of deep-focus long period (DFLP) earthquakes occurred in the zone (see Fig. 7); the generation of these events was discussed by Gorel'chik et al. (2004). A combined analysis of the seismic anomalies suggests the existence of a magma chamber in the lower crust beneath Klyuchevskoi. Its location is that of a previously identified conductivity anomaly (Moroz, 1991), which was later refined by numerical simulation of the electromagnetic field. The increased electrical conductivity in that zone is thought to be due to inclusions of fluids and melts (Moroz and Moroz, 2006). Magma comes into the chamber from a long-lived subcrustal source situated in the asthenosphere beneath the KVC. The existence of such a source in the upper mantle is corroborated by seismic observations. It is clearly seen in seismotomographic velocity images (Gontovaya et al., 2004, 2010; Fedotov et al., 2010;
Kulakov et al., 2016). It should be noted that these results provide no evidence of a direct supply of magma from the lower crustal source onto the ground surface.

\section{CONCLUSIONS}

The existence of magma chambers beneath Klyuchevskoi Volcano is inferred from numerous regularly occurring eruptions of the volcano and from the geochemical features of olivines and clinopyroxenes in moderate potassium magnesian and aluminiferous basalts and basaltic andesites. We made a compositional study of several thousand minerals and ejecta due to prehistorical and recent eruptions and of in situ chilled melt inclusions in the olivines of cinder lapilli discharged during the 1994 eruption. The result was to show on a natural object of study, for the first time during 100 years of research on Klyuchevskoi, that andesites can be derived from high-alumina basaltic melts. This inference is based on mineralogic data and argues for the existence of a shallow chamber. The inference is important for further study of the origin of andesites discharged by Bezymyannyi Volcano, which stands close to Klyuchevskoi. The dualism in the variation of the concentrations of $\mathrm{CaO}$ and $\mathrm{Al}_{2} \mathrm{O}_{3}$ in olivines and clinopyroxenes in high-alumina and magnesian basalts and basaltic andesites during crystallization provides evidence of deeper magnesian magma 
(a)
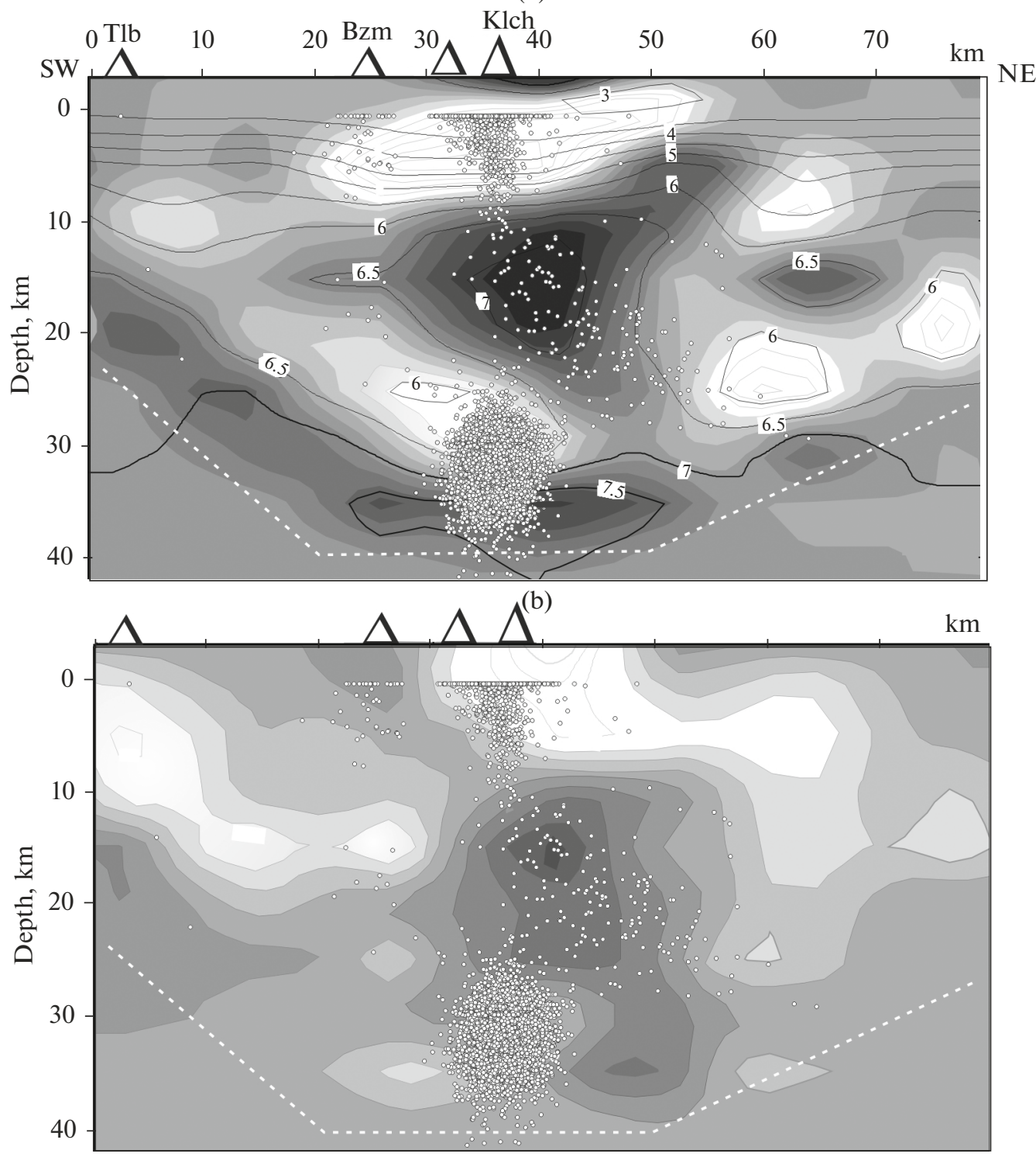

$\mathrm{P}$ and $\mathrm{S}$ velocity anomalies (in \%)

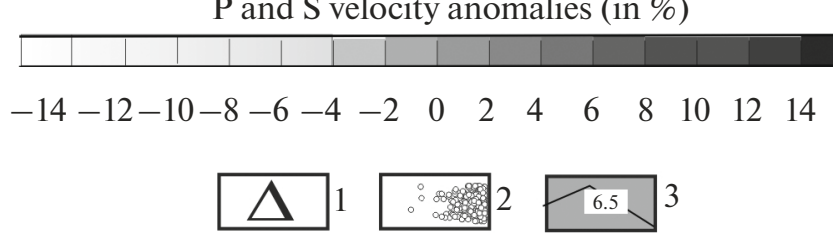

Fig. 8. Vertical sections of the 3-D crustal velocity model in anomalies of Vp (a) and Vs (b) beneath the Klyuchevskoi Volcanic Cluster. The whiter areas mark crustal volumes with lower Vp, while grey areas mark those volumes with higher Vp. The white dashed line separates the crustal volume where no observations of Vp and Vs are available. (1) Volcanic edifices; (2) earthquake hypocenters; (3) isolines of absolute velocities Vp (km/s). Tlb, Bzm, and Klch stand for Ploskii Tolbachik, Bezymyannyi, and Klyuchevskoi volcanoes, respectively.

being emplaced in the shallow high-alumina chamber during a resumed activity of the volcano. This is also indicated by the fact that the high-alumina basaltic andesites discharged by all parasitic vents contained high-magnesium minerals that are typical of mantle melts. The generation of all aluminiferous basaltic andesites discharged by parasitic vents was due to mixing of high-alumina and magnesian magmas that came from different peripheral sources. The decompressional crystallization of olivines $\left(\mathrm{Fo}_{93}\right)$ at the 
deeper magnesian source occurred in the spinel-olivine cotectic mode and continued with decreasing pressure and degassing of $\mathrm{H}_{2} \mathrm{O}$ as far as olivine $\mathrm{Fo}_{90}$. This was followed by simultaneous crystallization of olivines and clinopyroxenes in the deeper chamber, from $\mathrm{Mg} \# 90$ until Mg\#80. Magnesian magma crystallized with concomitant decreasing temperature without pressure changes. The decompressional crystallization terminated for an indefinite time and was probably resumed during a volcanic eruption. Olivines and clinopyroxenes whose magnesium number was below Mg\#80 mostly occurred in the shallow magma chamber, crystallizing from a high-alumina magma as it was rising and $\mathrm{H}_{2} \mathrm{O}$ degassing in the magnetite-olivineclinopyroxene-plagioclase cotectic mode. The results of petrologic studies are quite consistent with seismological and geoelectric observations. An analysis of seismological surveys (deep seismic sounding and refraction shooting, seismic tomography, and the frequency-magnitude distribution of earthquakes) to study the crustal structure and properties revealed a peripheral magma chamber beneath the Klyuchevskoi cone in the $25-35 \mathrm{~km}$ depth range. This is also corroborated by geoelectric data on conductivity anomalies associated with inclusions of fluids and melts. The shallow chamber is most likely situated between the folded unit and the top of the consolidated basement. The diameter of the shallow chamber is approximately $12-14 \mathrm{~km}$, while its thickness can reach $3 \mathrm{~km}$.

\section{ACKNOWLEDGMENTS}

We express our sincere gratitude to Academician S.A. Fedotov, Academician E.I. Gordeev, Dr. Sci. (Geol.-Mineral.) Yu.A. Taran, and Senior Researcher, Cand. Sci. (Geol.-Mineral.) A.P. Maksimov, for helpful discussions. We are also grateful to Senior Researcher Cand. Sci. (Geol.-Mineral.) D.A. Kuz'min and Senior Researcher Cand. Sci. (Geol.-Mineral.) V.G. Batanova for analyses of rocks and minerals at the Max Planck Institute for Chemistry (Mainz, Germany) and at the Institut des Sciences de la Terre at University Joseph Fourier, Grenoble, France.

This work was supported by the Russian Foundation for Basic Research, project no. 16-05-00059, and by grants 15-I-2-008 and 16-I-1-0127 of the FEB RAS.

\section{REFERENCES}

Anosov, G.I., Bikenina, S.K., Popov, A.A., et al., Glubinnoe seismicheskoe zondirovanie Kamchatki (Deep Seismic Sounding of Kamchatka), Moscow: Nauka, 1978.

Ariskin, A.A., Barmina, G.S., Ozerov, A.Yu., and Nik'sen, R.L., The genesis of aluminiferous basalts of Klyuchevskoi Volcano, Petrologiya, 1995, vol. 3, no. 5, pp. 496-521.

Balesta, S.T., Gontovaya, L.I., Kargopol'tsev, V.A., et al., Results of seismic studies of the Earth's crust in the region of Klyuchevskoi Volcano, Vulkanol. Seismol., 1991, no. 3, pp. 3-18.
Ermakov, V.A., Garagash, I.A., and Gontovaya, L.I., A model of tectono-magmatic processes in the Klyuchevskoi Volcanic Cluster: Geological and geophysical evidence, Vestnik KRAUNTs, 2014, no. 2, Issue 24, pp. 231-243.

Fedotov, S.A., Zharinov, N.A., and Gontovaya, L.I., The magmatic system of the Klyuchevskaya group of volcanoes inferred from data on its eruptions, earthquakes, deformation, and deep structure, J. Volcanol. Seismol., 2010, vol. 4, no. 1, pp. 1-33.

Fedotov, S.A., Zharinov, N.A., and Gorel'chik, V.I., Deformation and seismicity at Klyuchevskoi, a model for its activity, Vulkanol. Seismol., 1988, no. 2, pp. 342.

Fedotov, S.A., Utkin, I.S., and Utkina, L.I., The peripheral magma chamber of Ploskii Tolbachik, a Kamchatka basaltic volcano: Activity, location and depth, dimensions, and their changes based on magma discharge observations, J. Volcanol. Seismol., 2011, vol. 5, no. 6, pp. 369-385.

Feig, S.T., Koepke, J., and Snow, J., Effect of water on tholeiitic basalt phase equilibria: an experimental study under oxidizing conditions, Contrib. Mineral. Petrol., 2006, vol. 152, pp. 611-638.

Gavrilenko, M., Herzberg, C., Vidito, C., et al., A calciumin-olivine geohygrometer and its application to subduction zone magmatism, J. Petrology, 2016, vol. 57, no. 9, pp. 1811-1832.

Gontovaya, L.I., Khrenov, A.P., Stepanova, M.Yu., and Senyukov, S.L., A deep lithosphere model for the Klyuchevskoi Volcanic Cluster area, Kamchatka, Vulkanol. Seismol., 2004, no. 3, pp. 3-11.

Gontovaya, L.I., Popruzhenko, S.V., and Nizkous, I.V., Upper mantle structure in the ocean-continent transition zone: Kamchatka, J. Volcanol. Seismol., 2010, vol. 4, no. 4, pp. 232-247.

Gorel'chik, V.I., Garbuzova, V.T., and Storcheus, A.V., Deep-seated volcanic processes beneath Klyuchevskoi Volcano from seismological data, Vulkanol. Seismol., 2004, no. 6, pp. 21-34.

Hoffman, A.W., Chemical differentiation of the Earth: the relationship between mantle continental crust and oceanic crust, Earth Planet. Sci. Lett., 1988, vol. 73, pp. 287-310.

Ivanov, A.I., Koulakov, I.Yu., West, M., et al., Magma source beneath the Bezymiany volcano and its interconnection with Kluchevskoy inferred from local earthquake seismic tomography, J. Volcanol. Geotherm. Res., 2016. doi. jvolgeores, 2016. doi 10.2016/ j

Koulakov, I., Gordeev, E., Dobretsov, N., et al., Rapid changes in magma storage beneath the Klyuchevskoy group of volcanoes inferred from time dependent seismic tomography, J. Volcanol. Geotherm. Res., 2013, vol. 263, pp. 75-91. doi: es.2012.10.014. doi 10.1016./j.jvolgeor

Jarosevish, F.J., Nelen, J.A., and Norberg, J.A., Reference sample for electron microprobe analysis, Geostandards Newsletter, 1980, vol. 4, pp. 43-47.

Khubunaya, S.A., Bogoyavlenskii, S.O., Novgorodtseva, T.Yu., and Okrugina, A.M., The mineralogy of the Klyuchevskoi magnesian basalts depicting the fraction- 
ation in the magma chamber, Vulkanol. Seismol., 1993, no. 3, pp. 46-68.

Khubunaya, S.A., Gontovaya, L.I., Sobolev, A.I., and Nizkous, I.V., Magma chambers beneath the Klyuchevskoy Volcanic Group (Kamchatka), J. Volcanol. Seismol., 2007, vol. 1, no. 2, pp. 98-118.

Khubunaya, S.A., Gontovaya, L.I., and Moskaleva, S.V., The shallow magma chamber beneath Klyuchevskoi Volcano: Petrologic and geophysical evidence, in Materialy konferentsii, posvyashchennoi Dnyu vulkanologa (Proc. conf. devoted to Volcanologist's Day), March 29-30, 2008, Petropavlovsk-Kamchatskii, 2008, pp. 293-304.

Khubunaya, S.A. and Sobolev, A.V., Primary melts of calcalkaline magnesian basalts: Klyuchevskoi Volcano, Kamchatka, Dokl. Akad. Nauk, 1998, vol. 360, no. 1, pp. 100-102.

Khubunaya, S.A., Eremina, T.S., and Sobolev, A.V., The classification of potassium basaltic trachyandesites that were discharged by the 2012-2013 parasitic eruption on Ploskii Tolbachik Volcano, Kamchatka using geochemical criteria, J. Volcanol. Seismol., 2015, vol. 10, no. 1, pp. 33-49.

Koulakov, I.Yu., Kukarina, E.I., Gordeev, E.I., et al., Magma sources in the mantle wedge beneath the volcanoes of the Klyuchevskoi Volcanic Cluster and Kizimen Volcano, Kamchatka based on seismic tomography data, Geol. Geofiz., 2016, vol. 57, no. 1, pp. 109-124.

Menyailov, A.A., The dynamics and mechanism of eruption: Klyuchevskoi Volcano in 1937-1938, Trudy Lab. Vulkanol. St., Moscow-Leningrad: Akad. Nauk SSSR, 1947, no. 4, pp. 3-91.

Mironov, N.L., Portnyagin, M.V., Plechov, P.Yu., and Khubunaya, S.A., The terminal phases of the evolution of Klyuchevskoi, Kamchatka magmas: Melt inclusions in minerals of high-alumina basalts, Petrologiya, 2001, vo. 52(11), pp. 1736-1747.

Moroz, Yu.F., Elektroprovodnost' zemnoi kory i verkhnei mantii Kamchatki (The Electric Conductivity of the Crust and Upper Mantle in Kamchatka), Moscow; Nauka, 1991.

Moroz, Yu.F. and Moroz, T.A., Deep-seated conductive zones in the junction zone of the Kuril-Kamchatka and Aleutian island arcs, Fizika Zemli, 2006, no. 6, pp. $60-68$.
Ozerov, A.Yu., Karpov, G.A., Droznin, V.A., et al., The dynamics of the Klyuchevskoi, Kamchatka eruption of September 2 to October 2, 1994, Vulkanol. Seismol., 1996, no. 5, pp. 3-16.

Ozerov, A.Yu. and Khubunaya, S.A., The chemistry of olivines and pyroxenes as indicating a genetic relationship between aluminiferous and magnesian basalts: Klyuchevskoi Volcano, in Posteruptivnoe mineraloobrazovanie na aktivnykh vulkanakh Kamchatki (Posteruptive Mineral Generation on Active Kamchatka Volcanoes), Vladivostok, 1992, Part 2, pp. 37-61.

Piip, B.I., Klyuchevskoi Volcano and its eruptions in 19441945 and in the past, Trudy Lab. Vulkanol., 1956, issue 11 (special issue).

Piip, B.I., Efimova, E.A., and Gontovaya, L.I., An interpretation of seismic travel times along a refraction line in the Klyuchevskoi area, Vulkanol. Seismol., 1991, no. 5, pp. 83-91.

Sobolev, A.V. and Chaussidon, $\mathrm{M}$., $\mathrm{H}_{2} \mathrm{O}$ concentrations in primary melts from island arcs and mid-ocean ridges: Implications for $\mathrm{H}_{2} \mathrm{O}$ storage and recycling in the mantle, Earth Planet. Sci. Lett., 1996, vol. 137, nos. 1-4, pp. $45-55$.

Sobolev, A.V., Hofman, A.W., Kuzmin, D.V., et al., The amount of recycled crust in sources of mantle-derived melts, Science, 2007, vol. 316, no. 5823, pp. 412-417.

Stromer, J.C., Calcium zoning in olivine and its relationship to silica activity and pressure, Geochim. Cosmochim. Acta, 1973, vol. 37, pp. 1815-1821.

Vazheevskaya, A.A., The Basalts in Areal Zones of Kamchatka, Extended Abstract of Cand. Sci. (Geol.-Mineral.) Dissertation, Vladivostok, 1972, 28 pp.

Wiemer, S. and McNutt, R., Variations in the frequencymagnitude distribution with depth in two volcanic areas: Mount St. Helens, Washington, and Mt. Spurr, Alaska, Geophys. Res. Lett., 1997, vol. 24, no. 2, pp. 189-192.

Zavaritsky, A.N., Some volcanic rocks around Klyuchevskoi in Kamchatka, Zapiski Rossiiskogo Mineralogicheskogo Obshchestva, 1931, Ser. 11, pp. 10-15.

Zubin, M.I., Kozyrev, A.I., and Luchitskii, A.I., A gravity model for the structure of Klyuchevskoi Volcano, Kamchatka, Vulkanol. Seismol., 1990, no. 5, pp. 76-93.

Translated by A. Petrosyan 